\title{
Airway smooth muscle relaxation
}

\author{
Alan J Knox, Anne E Tattersfield
}

Respiratory Medicine Unit, City Hospital, Nottingham NG5 1PB, UK

A J Knox

A E Tattersfield

Reprint requests to: Dr A J Knox.

Received 7 November 1994 Returned to authors 8 February 1995

Revised version received 22 March 1995 Accepted for publication 1 May 1995
Bronchodilators are important agents in the treatment of asthma and chronic obstructive airways disease. Beta agonists, theophyllines, and antimuscarinic agents are the main drugs in current use, but others are under investigation. Although other actions may be important, these drugs produce bronchodilation either by a direct effect on airway smooth muscle or by inhibiting neural pathways. As our understanding of airway smooth muscle relaxant mechanisms increases, new therapeutic possibilities are being realised. Several recent findings contradict established dogma - for example, the assumption that $\beta$ agonists and theophyllines act solely via cyclic adenosine monophosphate (cAMP)-linked intracellular pathways has been questioned and studies with atrial natriuretic peptide and nitrates suggest that cyclic guanosine monophosphate (cGMP) may be an important relaxant second messenger. The role of potassium channel activators is being explored with the development of drugs which relax airway smooth muscle by a direct action on cell membrane ion channels. In this review we discuss what is known of the likely mechanisms of action of the airway smooth muscle relaxants in current use and their effects on calcium homeostasis, and suggest how developments in our understanding of relaxant mechanisms may aid the development of treatment for airways obstruction in the future. Agents such as the muscarinic, histamine or leukotriene antagonists which cause bronchodilatation by blocking the effects of neurotransmitters or mediators at the receptor level are not discussed, nor are the effects other than those on airway smooth muscle of bronchodilators in current use.

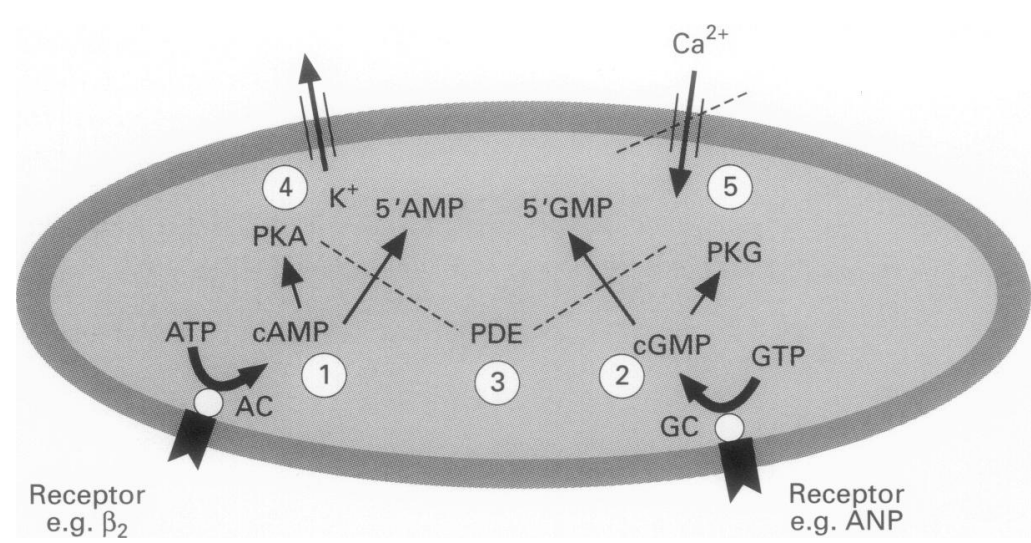

Figure 1 Main pathways of airway smooth muscle relaxation: (1) via receptors linked to $c A M P$; (2) via receptors linked to $c G M P$; (3) PDE (phosphodiesterase) inhibition; (4) activation of $\mathrm{K}^{+}$channels; (5) inhibition of $\mathrm{Ca}^{2+}$ channels. $\mathrm{AC}=$ adenylate cyclase; $P K A=$ protein kinase $A ; G C=$ guanylate cyclase; $P K G=$ protein kinase $G$.

\section{Role of calcium in relaxation of airway smooth muscle}

The drugs in current use cause relaxation of airway smooth muscle by stimulating a cyclic nucleotide second messenger system, predominantly cAMP and cGMP, by inhibiting the breakdown of cyclic nucleotides or by a direct action on cell membrane ion channels or transporters (table 1, fig 1).

Since the relation between an increase in intracellular calcium and contraction is well established, it is generally assumed that relaxation is preceded by a fall in intracellular calcium, although relatively few studies have investigated this. A fall in intracellular calcium (measured by aequorin luminescence) ${ }^{1}$ accompanied isoprenaline-induced relaxation in canine trachealis contracted with 5-hydroxytryptamine or cholinergic agonists and, since the fall in intracellular calcium correlated strongly with the reduction in tension, it was thought to be responsible. A fall in cellular calcium was also seen in cAMP-mediated relaxation in canine airway smooth muscle ${ }^{2}$ and in cGMP-mediated relaxation in canine and bovine airway smooth muscle. ${ }^{34}$ There was no fall in intracellular calcium in response to $\beta$ agonist in bovine tracheal smooth muscle in one study, ${ }^{5}$ and in some studies increases in intracellular calcium in response to $\beta$ agonists have been seen as a result of calcium influx through membrane channels under resting conditions. ${ }^{36}$ The inconsistencies seen in these studies may be due to the fact that the experiments which failed to show a reduction in calcium were carried out at $22^{\circ} \mathrm{C}$ when many intracellular processes, including $\mathrm{Na}^{+} / \mathrm{K}^{+} \mathrm{ATP}-$ ase, would be inhibited. On balance it seems likely that a fall in intracellular calcium is associated with relaxation in the same way that an increase in intracellular calcium is associated with contraction.

Table 1 Agents known to cause airway smooth muscle relaxation in vitro

\begin{tabular}{|c|c|c|}
\hline \multicolumn{2}{|c|}{ Mechanism } & \multirow{2}{*}{$\begin{array}{l}\text { Agent } \\
\beta \text { agonists, vasoactive intestinal } \\
\text { peptide, peptide histidine } \\
\text { isoleucine, pituitary adenylate } \\
\text { cyclase activating peptide } \\
\mathrm{PGE}_{2}, \mathrm{PGI}_{2}\end{array}$} \\
\hline 1. & $\begin{array}{l}\text { Agents acting through } \\
\text { stimulating cAMP }\end{array}$ & \\
\hline 2. & $\begin{array}{l}\text { Agents acting through } \\
\text { stimulating cGMP }\end{array}$ & $\begin{array}{l}\text { Nitric oxide, nitrosothiols } \\
\text { Nitrates, sodium nitroprusside } \\
\text { ANP, BNP, CNP }\end{array}$ \\
\hline 3. & $\begin{array}{l}\text { Inhibitors of cAMP, } \\
\text { GMP breakdown }\end{array}$ & Phosphodiesterase inhibitors \\
\hline 4. & Ion channels & $\begin{array}{l}\text { Calcium antagonists } \\
\text { Potassium channel activators } \\
\text { Sodium channel/transport } \\
\text { modulators }\end{array}$ \\
\hline 5. & Miscellaneous & $\begin{array}{l}\text { Anaesthetic agents } \\
\text { Lithium } \\
\text { Protein kinase } C \text { inhibitors } \\
\text { Calmodulin antagonists }\end{array}$ \\
\hline
\end{tabular}




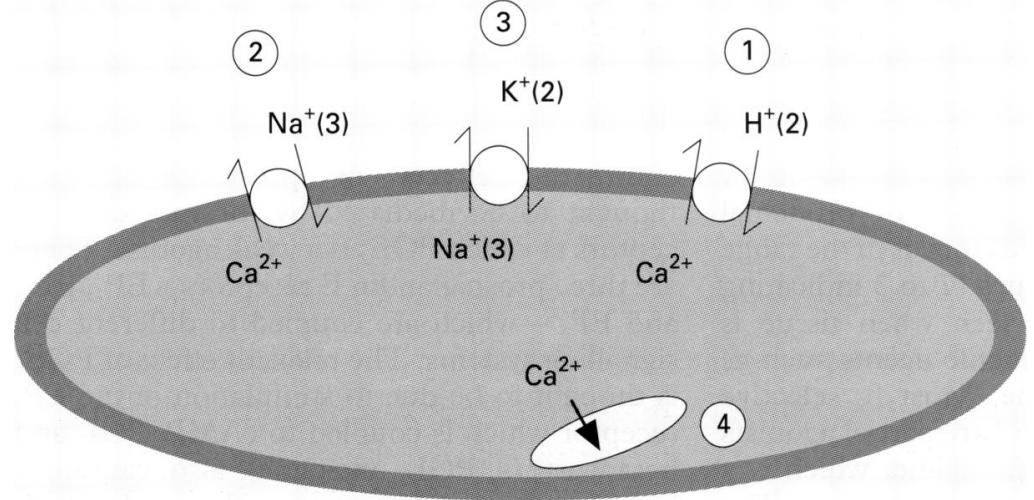

Figure 2 The main calcium removal mechanisms in airway smooth muscle: (1) $\mathrm{Ca}^{2+}$ $\mathrm{Mg}^{2+}$ ATPase; (2) $\mathrm{Na}^{+} / \mathrm{Ca}^{2+}$ exchanger which is linked to (3) $\mathrm{Na}^{+} / \mathrm{K}^{+}$ATPase; and (4) $\mathrm{Ca}^{2+}$ uptake by intracellular stores.

At least three calcium removal mechanisms are thought to lower intracellular calcium in airways smooth muscle: (1) calcium magnesium ATPase, (2) sodium-calcium exchange, and (3) uptake of calcium into intracellular organelles such as sarcoplasmic reticulum and mitochondria (fig 2).

\section{CALCIUM MAGNESIUM ATPASE (CALCIUM EFFLUX PUMP)}

The electroneutral calcium efflux pump found in the plasma membrane of most cells including smooth muscle ${ }^{8}$ is a magnesium- and ATPdependent enzyme which extrudes one calcium ion for two hydrogen ions. It is stimulated by a calcium-calmodulin complex which may act as a feedback mechanism to limit the rise in intracellular calcium following stimulation. ${ }^{8-10}$ Its activity also depends on the activity of AMPdependent protein kinases in several types of smooth muscle, ${ }^{11}$ although the only study to date on airway smooth muscle failed to show this. ${ }^{12}$

\section{SODIUM-CALCIUM EXCHANGE}

The sodium-calcium exchanger transports one calcium ion for three sodium ions and is driven by the sodium gradient across the membrane which, in turn, is maintained by $\mathrm{Na}^{+} / \mathrm{K}^{+} \mathrm{ATP}-$ ase. ${ }^{13}$ Although there is good evidence for

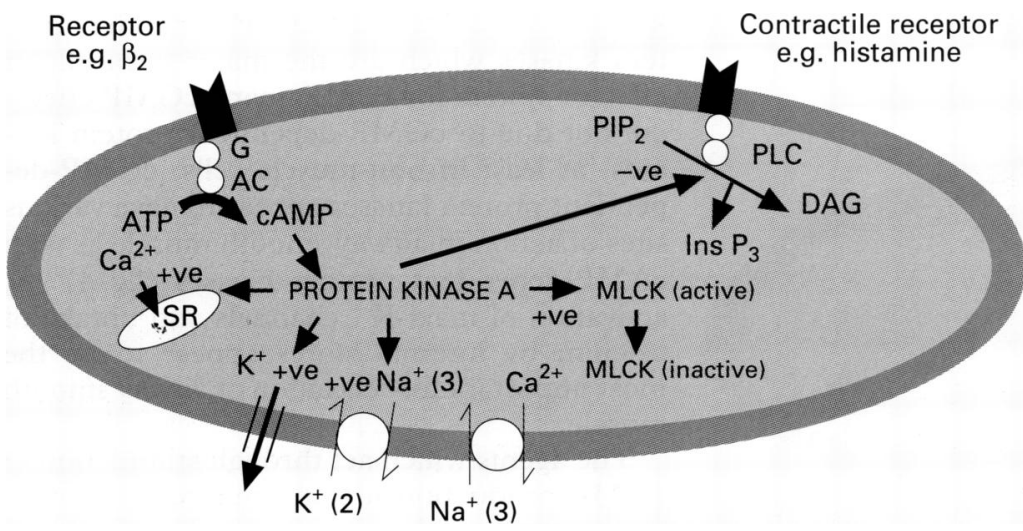

Figure 3 Schematic representation of the sites of phosphorylation for protein kinase $A$. The combined effect of phosphorylation at these sites is to lead to airway smooth muscle relaxation. $M L C K=$ myosin light chain kinase; $S R=$ sarcoplasmic reticulum; $P L C=$ phospholipase $C ; D A G=$ diacylglycerol; Ins $P_{3}=$ inositol trisphosphate; $P I P_{2}=$ inositol bisphosphate; $G=$ guanosine nucleotide binding protein; $A C=$ adenylate cyclase. sodium-calcium exchange in cardiac muscle, ${ }^{14}$ its presence in smooth muscle is less well established. ${ }^{15}$ Such a mechanism probably exists in the airways since reducing external sodium causes contraction of canine, ${ }^{16}$ bovine, ${ }^{1718}$ and human ${ }^{19}$ airway smooth muscle in vitro, and ion flux studies suggest that $\mathrm{Na}^{+} /$ $\mathrm{Ca}^{2+}$ exchange sites are abundant in bovine tracheal smooth muscle. ${ }^{20}$

\section{INTRACELLULAR CALCIUM REMOVAI MECHANISMS}

The sarcoplasmic reticulum and mitochondria are the most important intracellular organelles for the removal of calcium. The sarcoplasmic reticulum accumulates calcium via a cAMPdependent mechanism. ${ }^{8121}$ The mitochondria take up calcium, store it as a non-ionic calciumphosphate complex, and release it back into the cytosol via a calcium efflux pathway. ${ }^{22}$ The mitochondrial calcium store may protect the cell against calcium overload in pathological conditions, ${ }^{7}$ at least in cardiac muscle.

\section{Cyclic AMP-mediated relaxant mechanisms}

The cAMP pathway is the most important relaxant signal transduction pathway in airway smooth muscle. The $\beta_{2}$ adrenoceptor, the main receptor studied with respect to this pathway, is coupled through an intermediary stimulatory $\mathrm{G}$ protein $\left(\mathrm{G}_{\mathrm{s}}\right)$ to adenylate cyclase which catalyses the intracellular conversion of ATP to cAMP. Adenylate cyclase can also be inhibited through muscarinic $M_{2}$ receptors via an inhibitory $\mathrm{G}$ protein $\left(\mathrm{G}_{\mathrm{i}}\right)$. cAMP activates a group of cyclic AMP-dependent protein kinases (protein kinase A) which, in turn, phosphorylate a number of different substrates which then cause relaxation. The precise way in which cAMP causes relaxation is still not clear. Several actions of cAMP-dependent protein kinases which can cause relaxation have been identified (fig 3). These include inhibition of inositol phosphate hydrolysis, ${ }^{2324}$ increased calcium uptake by internal stores, ${ }^{25}$ inactivation of myosin light chain kinase, ${ }^{26}$ and activation of cell membrane ion channels and transporters such as $\mathrm{K}^{+}$channels ${ }^{27}$ and $\mathrm{Na}^{+} / \mathrm{K}^{+}$ATPase. ${ }^{2829}$ The net effect of these processes would be to reduce intracellular calcium concentration and increase contractile protein phosphorylation, thereby producing relaxation. Although protein kinase $\mathrm{A}$ has been shown to produce effects at these sites in vitro, the relative importance of each mechanism in mediating the relaxant effects of $\beta$ adrenoceptor agonists in vivo is still unclear. Recent work in porcine and ferret airway smooth muscle suggests that $\beta$ agonists can produce relaxation independently from elevation of cAMP via stimulation of the GTP binding protein of adenylate cyclase $\left(G_{s}\right)$ coupled to maxi- $\mathrm{K}^{+}$channels. ${ }^{30}$ The effect of $\mathrm{G}_{\mathrm{s}}$ and protein kinase $A$ on the maxi- $\mathrm{K}^{+}$channel is additive. $^{30}$

Agents which act through stimulation of cAMP production include $\beta_{2}$ adrenoceptor agonists, vasoactive intestinal peptide and prostaglandins. 


\section{$\beta_{2}$ ADRENOCEPTOR AGONISTS}

Beta $_{2}$ agonists increase intracellular cAMP levels ${ }^{31}$ and are potent relaxants of airway smooth muscle in several species including man. ${ }^{32}$ The negative log molar $\mathrm{EC}_{50}$ value for isoprenaline-induced relaxation of bronchial smooth muscle spontaneous tone is in the range of 9 to $7,^{32}$ with lower values (7 to 3 indicating reduced potency) being seen when tissue is preconstricted with contractile agents such as histamine or acetylcholine. Most $\beta_{2}$ selective agonists such as salbutamol are partial agonists when compared with isoprenaline, which is a full but non-selective $\beta$ agonist in vitro. The effects of $\beta_{2}$ agonists in vitro can be mimicked by direct activators of adenylate cyclase such as forskolin.

The new $\beta_{2}$ adrenoceptor agonists, formoterol and salmeterol, produce more potent and prolonged relaxation of guinea pig trachea and human bronchial smooth muscle in vitro than drugs such as salbutamol. ${ }^{3334}$ The negative $\log$ molar $\mathrm{EC}_{50}$ values for relaxation of human bronchial smooth muscle is 9.6 for formoterol and 7.6 for salmeterol. ${ }^{35}$ Both drugs are more lipophilic than salbutamol and it has been postulated that non-specific binding to the cell membrane or binding to an exoreceptor may prolong their action. ${ }^{35}$ Salmeterol is a partial agonist compared with both isoprenaline and salbutamol. ${ }^{36}$

\section{VASOACTIVE INTESTINAL PEPTIDE (VIP)}

VIP immunoreactivity has been demonstrated in nerve fibres in the airway ${ }^{37}$ and VIP receptors have been identified on airway smooth muscle. ${ }^{38}$ VIP relaxes airway smooth muscle from several species including human airways and is a potent bronchodilator. ${ }^{39}$ Its effect on human airways is enhanced by epithelial removal and peptidase inhibition. ${ }^{40}$ Part of its action may be due to $\mathrm{Na}^{+} / \mathrm{K}^{+}$ATPase activation since relaxation in rabbit airway smooth muscle is inhibited by the $\mathrm{Na}^{+} / \mathrm{K}^{+}$ ATPase inhibitor ouabain. ${ }^{41}$

\section{PROSTAGLANDINS}

Prostaglandin $\mathrm{E}_{2}\left(\mathrm{PGE}_{2}\right)$ relaxes canine airway smooth muscle. ${ }^{28}$ In human airway smooth muscle at low concentrations it increases CAMP

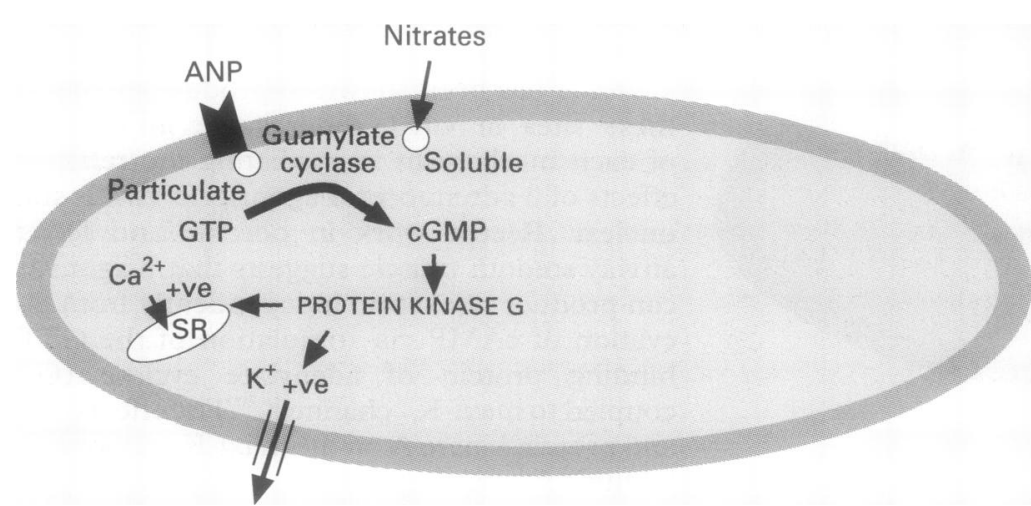

Figure 4 Sites of phosphorylation for protein kinase $G$ which have been shown in airway smooth muscle. $S R=$ sarcoplasmic reticulum. Other possible sites demonstrated in non-airway smooth muscle include inhibition of inositol phospholipid turnover ${ }^{s 5}$ and decreased sensitivity of contractile proteins to calcium. ${ }^{53}$ via adenylate cyclase ${ }^{31}$ and causes relaxation, whereas at higher concentrations it causes contraction. ${ }^{42-44}$ This can probably be explained by its actions on different receptors. ${ }^{45}$ The contractile effects of prostaglandins are thought to be mediated by thromboxane receptors at which $\mathrm{PGE}_{2}$ is a weak agonist. There are three prostaglandin $\mathrm{E}$ receptors $-\mathrm{EP}_{1}, \mathrm{EP}_{2}$, and $\mathrm{EP}_{3}$ - which are coupled to different cell signalling systems. The relaxant effect of $\mathrm{PGE}_{2}$ is thought to be due to stimulation of the $\mathrm{EP}_{2}$ receptor which is coupled to cAMP. $\mathrm{PGI}_{2}$ and beraprost (a $\mathrm{PGI}_{2}$ analogue) also cause relaxation of canine airway smooth muscle which can be inhibited by inhibitors of adenylate cyclase, suggesting that cAMP pathways are involved. ${ }^{46}$

\section{OTHERS}

Peptide histidine isoleucine (PHI) and its human equivalent, peptide histidine methionine (PHM), share structural similarities with VIP and have a similar immunocytochemical distribution in the lung. PHI is a potent relaxant of human bronchi in vitro, ${ }^{39}$ whilst pituitary adenylate cyclase activating peptide (PACAP) has been shown to relax rabbit and guinea pig airway smooth muscle by increasing cAMP. ${ }^{4047}$

\section{Cyclic GMP relaxant mechanisms (figs 1, 4)}

It has become clear that cGMP produced by guanylate cyclase is also a relaxant second messenger in airway smooth muscle. ${ }^{48}$ Guanylate cyclase exists in two forms - a soluble and a particulate form - both of which have been purified and characterised. ${ }^{490}$ Soluble guanylate cyclase is a haem protein which exists as a heterodimer composed of two subunits; it is activated by nitric oxide and the nitro group of vaso/bronchodilators. Particulate guanylate cyclase is one of the receptors mediating the effects of atrial natriuretic peptide. ${ }^{4950}$ Guanylate cyclase catalyses the conversion of GTP to cGMP which then activates a group of distinct cGMP-dependent protein kinases. Considerable sequence homology exists between cGMP-dependent protein kinases and other kinases, particularly cAMP-dependent protein kinases. ${ }^{50}$ In contrast to cAMP-dependent protein kinases which are the major intracellular effector system for cAMP, many cGMP effects are not due to cGMP-dependent protein kinases, at least in non-muscle cells. cGMP-dependent protein kinases appear to have various sites of action in airway smooth muscle as with cAMP-dependent protein kinases (fig 4) ${ }^{51-55}$; activation of maxi- $\mathrm{K}^{+}$channels and uptake of calcium by internal stores appear to be the most important for relaxation of airway smooth muscle..$^{5254}$

The agents which act through stimulation of cGMP production include nitrates and atrial natriuretic peptide.

\section{NITRATES}

Glyceryl nitrate, sodium nitroprusside and the cell permeable cGMP analogue, 8-bromo- 


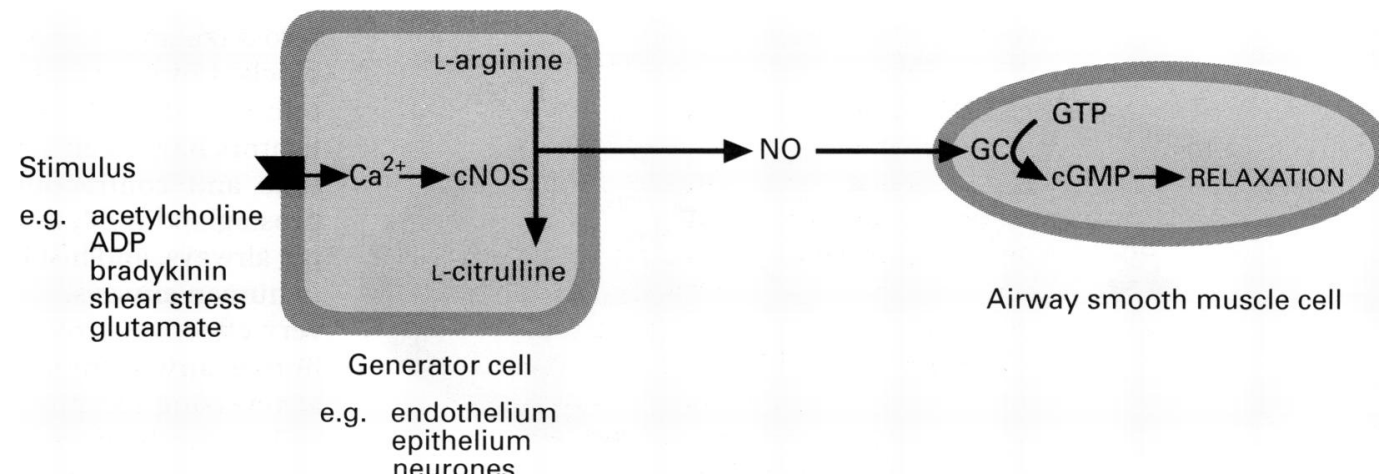

Figure 5 Mechanism whereby nitric oxide (NO) might bring about relaxation of airway smooth muscle. cNOS= constitutive nitric oxide synthase; $G C=$ guanylate cyclase.

cGMP, have been shown to relax canine and bovine airway smooth muscle ${ }^{56-58}$ and, in the case of sodium nitroprusside, human airway smooth muscle. ${ }^{59} \mathrm{~S}$-nitrosothiols, which consist of nitric oxide linked to a thiol group and are found endogenously in airway secretions, relax guinea pig and human airway smooth muscle. ${ }^{60}$ Dissolved nitric oxide gas relaxed bovine trachealis in one study. ${ }^{61}$ Endogenous nitric oxide and S-nitrosothiols are produced by cells such as airway epithelium and non-adrenergic noncholinergic nerves and may be involved in the regulation of bronchomotor tone (fig 5).$^{62}$ This effect might, however, be offset by proinflammatory actions of nitric oxide. ${ }^{62}$

\section{ATRIAL NATRIURETIC PEPTIDE}

Atrial natriuretic peptide (ANP) relaxes guinea pig $^{63}$ and bovine ${ }^{64}$ airway smooth muscle and this is associated with increased cGMP ${ }^{64}$ in bovine airway smooth muscle. ANP is degraded rapidly by epithelial peptidases and the response to ANP is enhanced by removing epithelium or adding a peptidase inhibitor. ${ }^{65}$ The effects of ANP appear to be less marked in human airway smooth muscle. ${ }^{66-68}$ Two related peptides, brain natriuretic peptide (BNP) and C-type natriuretic peptide (CNP), have been shown to increase cGMP and relax guinea pig airway smooth muscle, but have not been studied in man. ${ }^{6970}$

\section{Agents preventing the breakdown of cAMP and cGMP}

A family of phosphodiesterase enzymes hydrolyse the 3'-phosphoester bond on cAMP

Table 2 Phosphodiesterase isoenzymes in airway smooth muscle

\begin{tabular}{|c|c|c|}
\hline \multicolumn{2}{|c|}{ Isoenzymes } & \multirow{2}{*}{$\begin{array}{l}\text { Species } \\
\text { Canine, bovine, human }\end{array}$} \\
\hline I & $\begin{array}{l}\mathrm{Ca}^{2+} / \text { calmodulin- } \\
\text { stimulated }\end{array}$ & \\
\hline II & cGMP-stimulated & Canine, bovine, human \\
\hline III & cGMP-inhibited & Canine, guinea pig, human \\
\hline IV & cAMP-specific & $\begin{array}{l}\text { Canine, guinea pig, bovine, } \\
\text { human }\end{array}$ \\
\hline V & cGMP-specific & Canine, human \\
\hline VI & cGMP-specific & None to date \\
\hline VII & $\begin{array}{l}\text { cAMP-specific, } \\
\text { rolipram insensitive }\end{array}$ & None to date \\
\hline
\end{tabular}

and cGMP converting them to their inactive $5^{\prime}$ nucleotide metabolites 5'-AMP and 5'-GMP. Theophylline and other xanthine derivatives cause airway smooth muscle relaxation in vitro and bronchodilatation in vivo, and although they may have other mechanisms of action, phosphodiesterase (PDE) inhibition appears to be important for smooth muscle relaxation. ${ }^{71}$ Theophylline has been shown to relax smooth muscle from several species including man when contracted with a wide range of spasmogens in vitro, ${ }^{72}$ although it is some 1000 times less potent than isoprenaline in relaxing human bronchi contracted by moderate doses of carbachol. ${ }^{73}$ Theophylline is a rather nonselective inhibitor of tissue phosphodiesterases and this is one factor underlying its narrow therapeutic index.

Recent studies have identified at least seven classes of PDE isoenzymes, each of which has several isoforms (table 2). These isoenzymes vary in their tissue distribution and their ability to break down cAMP and cGMP. ${ }^{745}$ Airway smooth muscle contains several PDE isoenzymes in most species and in human airway smooth muscle types III, IV and, to a lesser extent, $\mathrm{V}$ are important for relaxation. ${ }^{76-79}$ Drugs which inhibit specific isoenzymes may be relatively tissue selective in their effects and thus have advantages over theophylline. Studies of some of the more specific type IV inhibitors are currently under investigation in man.

\section{Drugs acting on cell membrane ion transport} CALCIUM CHANNEL ANTAGONISTS

Voltage-dependent calcium channel antagonists such as verapamil, gallopamil, nicardipine, and nifedipine inhibit the contractile response to depolarising agents and to various spasmogens (histamine, cholinergic agonists, leukotriene $\mathrm{D}_{4}$ ) in isolated airway smooth muscle from several species including man. ${ }^{80-84}$ They also reduce the response of sensitised guinea pig and human airway smooth muscle to antigen, ${ }^{8586}$ the order of potency for this effect being nifedipine >verapamil >diltiazem. The effects of the drugs in vitro have generally been modest even with high drug concentrations; this may be because the initiation of airway smooth muscle contraction is due to 


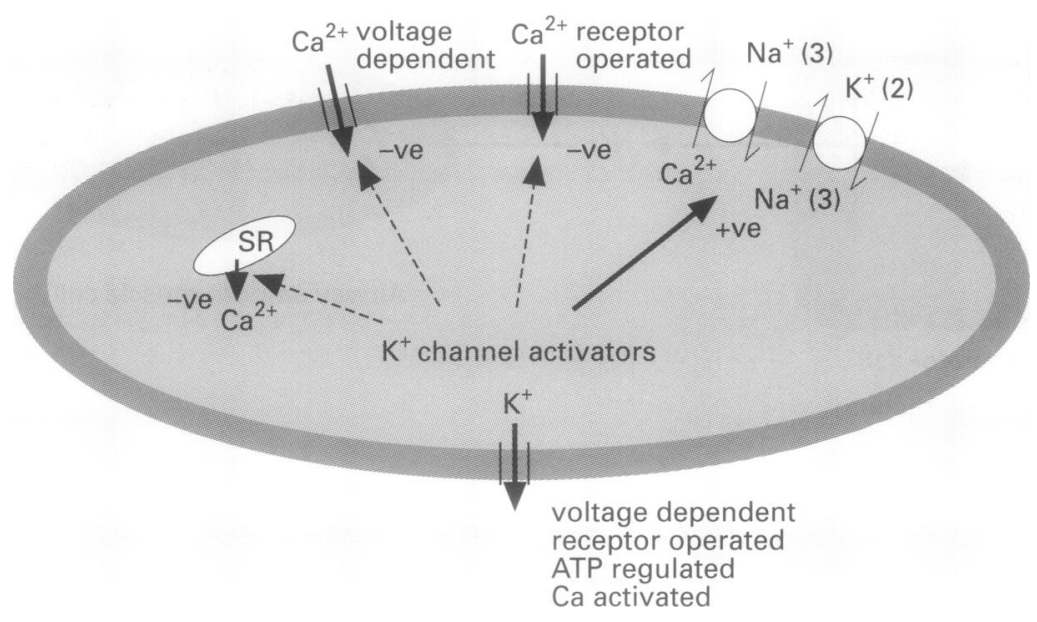

Figure 6 Mechanisms whereby $K^{+}$channel activation is thought to produce airway smooth muscle relaxation. $S R=$ sarcoplasmic reticulum.

release of calcium from internal stores rather than calcium influx. A receptor operated calcium channel has been shown to be responsible for calcium entry during the maintenance phase of the contractile response in cultured human airway smooth cells. ${ }^{87}$ Whether inhibitors of this channel might have a role as airway smooth muscle relaxants awaits further study. Calcium antagonists in current use have proved disappointing in studies of asthma in vivo.

POTASSIUM CHANNEL ACTIVATORS

The electrical stability of airway smooth muscle is controlled by $\mathrm{K}^{+}$channels. ${ }^{889}$ The two which have generated the most interest with respect to airway smooth muscle relaxation are the maxi- $\mathrm{K}^{+}$channel and the ATP regulated channel (fig 6). Activation of $\mathrm{K}^{+}$channels causes membrane hyperpolarisation in airway smooth muscle.

CALCIUM ACTIVATED CHANNELS (MAXI-K)

The large conductance $\mathrm{K}^{+}$channels (maxi-K) found in airway smooth muscle from several species including $\operatorname{man}^{90-93}$ are activated by calcium and inhibited by charybdotoxin. Maxi$\mathrm{K}^{+}$channels may have a role in both cAMP and cGMP-mediated airway smooth muscle relaxation. The channels are activated by cAMP-dependent protein kinase in rabbit trachea ${ }^{27}$ and directly by cAMP in porcine and ferret trachea ${ }^{30}$ and, when inhibited by charybdotoxin, cAMP-mediated relaxation of guinea pig and human airway smooth muscle $e^{9495}$ and cGMP-mediated relaxation in bovine airway smooth muscle ${ }^{58}$ are inhibited. Functional antagonism could be responsible for these inhibitory effects, however. Charybdotoxin can cause calcium influx through voltagedependent calcium channels, and the inhibitory effect of charybdotoxin on isoprenalineinduced relaxation in guinea pig trachea is inhibited by nifedipine. ${ }^{96}$

METABOLICALLY CONTROLLED CHANNELS ATP-sensitive $\mathrm{K}^{+}$channels open in response to a reduction in ATP and $\mathrm{K}^{+}$channel activators (cromakalim, nicorandil, pinacidil) and are blocked by the sulphonylureas (glibenclamide, tolbutamide, chlorpropamide). $\mathrm{K}^{+}$channel activators have been shown to relax spontaneous tone and contraction induced by histamine, prostaglandin $\mathrm{D}_{2}$, and leukotriene $\mathrm{C}_{4}$ in guinea pig airways, and histamine and cholinergic tone in human airways. ${ }^{97-100} \mathrm{~K}^{+}$channel openers are very effective at reducing spontaneous tone in human airway smooth muscle but less effective at reversing receptor-mediated contraction. ${ }^{101}$

The mechanisms by which $\mathrm{K}^{+}$channel activators cause airway smooth muscle relaxation is uncertain but are likely to include (a) membrane hyperpolarisation with reduction of calcium influx via voltage-dependent calcium channels; (b) activation of $\mathrm{Na}^{+} / \mathrm{K}^{+}$ATPase causing a decrease in intracellular $\mathrm{Na}^{+}$and, as a consequence, $\mathrm{Ca}^{2+}$ efflux via $\mathrm{Na}^{+} / \mathrm{Ca}^{2+}$ exchange; and (c) possibly the regulation of intracellular calcium release (fig 6). ${ }^{102}$

The drugs currently available lack specificity for the airways and, although some bronchodilatation has been seen in patients with asthma, systemic side effects such as hypotension have been a problem.

\section{SODIUM}

Smooth muscle contains several exchangers which regulate intracellular sodium including the $\mathrm{Na}^{+} / \mathrm{Ca}^{2+}$ exchanger, $\mathrm{Na}^{+} / \mathrm{K}^{+}$ATPase, and the $\mathrm{Na}^{+} / \mathrm{H}^{+}$antiport. Intracellular sodium is closely linked to intracellular calcium through the $\mathrm{Na}^{+} / \mathrm{Ca}^{2+}$ exchanger, so changes in intracellular sodium or in sodium exchange systems can affect relaxation. The $\mathrm{Na}^{+} / \mathrm{H}^{+}$ antiport may also alter the contractile status of the cell by regulating intracellular $\mathrm{pH}$. Activation of $\mathrm{Na}^{+} / \mathrm{K}^{+}$ATPase reduces intracellular sodium causing an increase in calcium efflux via $\mathrm{Na}^{+} / \mathrm{Ca}^{2+}$ exchange. There is evidence that activation of $\mathrm{Na}^{+} / \mathrm{K}^{+}$ATPase is important for drugs which act through cAMP such as $\beta$ agonists, but not those that act through cGMP. $\mathrm{Na}^{+} / \mathrm{K}^{+}$ATPase activity is increased by protein kinase $\mathrm{A}$ but not protein kinase $G$ in canine airway smooth muscle membrane particulates, ${ }^{29}$ and inhibition of $\mathrm{Na}^{+} /$ $\mathrm{K}^{+}$ATPase with ouabain inhibits the relaxant responses to drugs that act through cAMP such as $\beta$ agonists, but not those that act through cGMP such as nitroprusside. ${ }^{2829}$ Activators of $\mathrm{Na}^{+} / \mathrm{K}^{+}$ATPase or $\mathrm{Na}^{+} / \mathrm{Ca}^{2+}$ exchange would therefore be expected to act as airway smooth muscle relaxants. No such agents are currently available.

Amiloride, a non-specific inhibitor of sodium channels and transport processes including $\mathrm{Na}^{+}$entry channels, $\mathrm{Na}^{+} / \mathrm{H}^{+}$and $\mathrm{Na}^{+} / \mathrm{Ca}^{2+}$ exchange, relaxes airway smooth muscle tone and inhibits receptor-operated contraction in canine and bovine trachealis and the response to antigen in guinea pig airways in vitro. ${ }^{103-105}$ Further studies suggest that this effect may be due to inhibition of $\mathrm{Na}^{+}$entry channels ${ }^{106}$ or protein kinase $\mathrm{C}^{107}$ rather than inhibition of $\mathrm{Na}^{+} / \mathrm{H}^{+}$exchange or $\mathrm{Na}^{+} / \mathrm{Ca}^{2+}$ exchange. Inhaled amiloride caused no bronchodilatation, however, in one study of normal and asthmatic subjects. ${ }^{108}$ 


\section{Miscellaneous}

These are several other post-receptor sites where drugs could modify the relaxant processes in airway smooth muscle including guanosine nucleotide regulatory proteins (G proteins), calcium uptake into intracellular stores, and enzymes regulating the contractile process such as calmodulin, protein kinase C, and myosin light chain kinase. Few agents which affect these processes have been studied. Calmodulin antagonists have been shown to inhibit contraction in response to antigen in guinea pig trachea, ${ }^{85} 109$ but in general these agents lack specificity. The putative protein kinase $\mathrm{C}$ inhibitors $\mathrm{H}-7$ and staurosporine inhibit contractile responses to spasmogens in guinea pig $^{110}$ and bovine ${ }^{107}$ airway smooth muscle, but the drugs also lack specificity and have other effects such as inhibition of myosin light chain kinase.

Lithium, which inhibits myoinositol phosphate leading to depletion of membrane phospholipid pools, causes relaxation and protects against histamine-induced contraction in guinea pig airways in vitro. ${ }^{111}$ Lithium also reduces the airway response to histamine in asthmatic subjects. ${ }^{112}$

Some anaesthetic agents such as the benzodiazepines, halothane, and ketamine have been shown to relax airway smooth muscle in various animal species. ${ }^{113-115}$ This may be relevant for the treatment of acute asthma in intensive care units.

\section{Conclusion}

The pharmacology of airway smooth muscle is complex due to the wide range of effects of receptors and ion channels on airway smooth muscle cells and the complex post-receptor mechanisms involved in the contractile and relaxant responses. This provides a wide range of potential sites for pharmacological agents to produce relaxation of airway smooth muscle.

Of the established smooth muscle relaxant drugs, $\beta_{2}$ adrenergic agonists are currently the most useful. Advances are being made in several areas, however. Modifications to the structure of $\beta_{2}$ adrenergic agonists have produced agents with a longer duration of action. Identification of different isoenzymes of phosphodiesterase and the development of selective isoenzyme inhibitors may produce drugs which can exert tissue selectivity by acting an isoenzymes present in airway smooth muscle tissue but no other tissues. This might prevent some of the undesirable side effects seen with non-selective phosphodiesterase inhibitors such as theophylline.

Ion channel inhibitors or activators have proved disappointing therapeutic agents to date. Although the calcium channel antagonists have relaxant properties in vitro, they have not proved useful in vivo. The potassium channel activators have additional properties to inhibition of calcium entry via voltage-dependent calcium channels but greater specificity for airway smooth muscle is needed if they are to be useful relaxant agents.

A number of other steps in the contractile and relaxant responses are open to targeting by pharmacological agents, including modulation of $G$ proteins, the inositol phospholipid cascade and calcium release mechanisms, calmodulin and protein kinase $\mathrm{C}$. There is also potential for drugs which facilitate calcium extrusion across the cell membrane by activating sodium-calcium exchange, sodium potassium ATPase, or calcium magnesium ATPase. Airway smooth muscle pharmacology is an exciting and developing area for which the future holds much promise.

We thank Hilary Hughes for typing the manuscript and Daniel Duthie for work on the graphics.

1 Gunst SS, Bandyopadhyay S. Contractile force and in tracellular $\mathrm{Ca}^{2+}$ during relaxation of canine tracheal smooth muscle. Am f Physiol 1989;257:C355-64.

2 Ozahi H, Kiron S-C, Tajimi M, Karaki H. Changes in cytosolic $\mathrm{Ca}^{2+}$ and contraction induced by various stimulants and relaxants in canine tracheal smooth muscle. Pfugers Arch 1990;416:351-9.

3 Felbel J, Trockur B, Ecker T, Landgraf W, Hoffman F. Regulation of cytosolic calcium by CAMP and cGMP in freshly isolated smooth muscle cells from bovine trachea. f Biol Chem 1988;263:16764-71.

4 Jones KA, Lorenz RR, Warner DO, Katusic ZS, Sieck GC Changes in cytosolic cGMP and calcium in airway smooth muscle relaxed by 3-morpholinosydnonimine. $A m \mathcal{f}$ Physiol 1994;266:L9-16.

5 Takuwa Y, Takuwa N, Rasmussen H. The effects of isoproterenol on intracellular calcium concentration. $\mathcal{F}$ Biol Chem 1988;263:762-8.

6 Rasmussen H, Kelley G, Douglas JS. Interactions between $\mathrm{Ca}^{2+}$ and cAMP messenger system in regulation of airway smooth muscle contraction. Am 7 Physiol 1990;258. L 27988 .

7 Rodger I. Biochemistry of airway smooth muscle contraction. In: Barnes PJ, Rodger I, Thomson N, eds. traction. In: Barnes PJ, Rodger 1, Thomson N, eds. don: Academic Press, 1988:57-79.

8 Hogaboom GK, Fedan JS. Calmodulin stimulation of $\mathrm{Ca}^{2+}$ uptake and $\mathrm{Ca}^{2+}-\mathrm{Mg}^{2+}$ ATPase activities in microsomes from canine tracheal smooth muscle. Biochem Biophys Res Commun 1981;99:737-44.

9 Vincenzi FF, Hines TR, Raess BV. Calmodulin and the plasma membrane calcium pump. Ann NY Acad Sci 1980; 256:233-44.

10 Waisman DM, Gimble J, Goodman DPB, Rasmussen H. Studies of the $\mathrm{Ca}^{2+}$ transport mechanism of human insideout plasma membrane vesicles. I Regulation of the $\mathrm{Ca}^{2}$ pump by calmodulin. $\mathcal{F}$ Biol Chem 1981;256:409-14.

11 Daniel EE, Grover AK, Kwan CY. Calcium. In: Stephen NL, ed. Biochemistry of smooth muscle, Vol III, Boca Raton, Florida: CRC Press, 1983:1-88.

12 Sands H, Mascali J. Effects of cyclic AMP and of protein kinase on the calcium uptake by various tracheal smooth muscle organelles. Arch Int Pharmacodyn Ther 1978;236: 180-91.

13 Blaustein MP. The interrelationship between sodium and calcium fluxes across cell membranes. Rev Physiol Biochem Pharmacol 1974;70:33-82.

14 Smith TW, Antman EM, Fridman PL, Blatt CM, Marsh JD. Digitalis glycosides: mechanisms and manifestations of toxicity. Progress in Cardiovascular Disease. Vox XXVI No 6. New York: Grune and Stratton, 1984:413-59.

15 Brading AF, Lategan TW. $\mathrm{Na}^{+}-\mathrm{Ca}^{2+}$ exchange in vascular smooth muscle. F Hypertension 1985;3:109-16.

16 Ito I, Inoue T. Contracture and change in membrane potential produced by sodium removal in the dog trachea tential produced by sodium removal in the dog
and bronchiole. $₹$ Appl Physiol 1989;67:2078-86.

17 Bullock CG, Fettes JJF, Kirkpatrick CT. Tracheal smooth muscle:- second thoughts on sodium-calcium exchange. $\mathcal{f}$ Physiol 1981;318:46P.

18 Knox AJ, Ajao P, Tattersfield AE. The effect of removal of external sodium on airway smooth muscle tone. Am Rev Respir Dis 1989;139:A353.

19 Chideckel EW, Frost JL, Mike P, Fedan JS. The effect of ouabain on tension in isolated respiratory tract smooth muscle of humans and other species. Br 7 Pharmacol 1987;92:609-14.

20 Slaughter RS, Welton AF, Morgan DW. Sodium-calcium exchange in sarcolemmal vesicles from tracheal smooth muscle. Biochim Biophys Acta 1987;904:92-104.

21 Grover AK, Kannan MS, Daniel EE. Canine trachealis membrane fractionation and characterisation. Cell Calcium 1980;1:135-46.

22 Borie AB. Control, modulation and regulation of cell calcium. Rev Physiol Biochem 1981;90:13-153.

23 Madison JM, Brown JK. Differential effects of forskolin, isoproterenol, and dibutyryl-cyclic adenosine monophosphate on phosphoinositide hydrolysis in canine tracheal smooth muscle. F Clin Invest 1988;82:1462-5.

24 Hall IP, Donaldson J, Hill SJ. Inhibition of histamine stimulated inositol phospholipid hydrolysis by agents which increase cyclic AMP levels in bovine tracheal smooth muscle. Br f Pharmacol 1989;97:603-13.

25 Mueller E, Van Breeman C. Role of intracellular $\mathrm{Ca}^{2+}$ 
sequestration in beta adrenergic relaxation of airway smooth muscle. Nature 1979;281:682-3.

26 Silver P, Stull JT. Phosphorylation of myosin light chain and phosphorylase in tracheal smooth muscle in response to $\mathrm{KCl}$ and carbachol. Mol Pharmacol 1982:25:267-74.

27 Kume H, Takai A, Tokuno H, Tomita T. Regulation of $\mathrm{Ca}^{2+}$-dependent $\mathrm{K}^{+}$channel activity in tracheal myocytes by phosphorylation. Nature 1989;341:152-4.

28 Gunst SS, Stropp JQ. Effect of $\mathrm{Na}^{+}-\mathrm{K}^{+}$adenosinetriphosphatase activity on relaxation of canine tracheal smooth muscle. f Appl Physiol 1988;64:635-41.

29 Knox AJ, Brown JK. Differential regulation of $\mathrm{Na}^{+} / \mathrm{K}^{+}$ ATPase by the cyclic nucleotide dependent protein kinases in airway smooth muscle. Clin Res 1991;39:331A.

30 Kume H, Kotlikoff MI. Dual pathways of $\beta$-adrenergic action on $\mathrm{K} / \mathrm{Ca}^{2+}$ channels of tracheal smooth muscles. Am Rev Respir Dis 1993;147:A208.

31 Hall IP, Widdops S, Townsend P, Daykin K. Control of cyclic AMP levels in primary culture of human tracheal

32 Goldie RG, Spina D, Henry PJ, Lulich KM, Paterson JW. In vitro responsiveness of human asthmatic bronchus to carbachol, histamine, beta-adrenoceptor agonists and theophylline. Br 7 Clin Pharmacol 1986;22:669.

33 Jack D. A way of looking at agonism and antagonism: Lessons from salbutamol, salmeterol and other $\beta$-adrenoceptor agonists. Br f Clin Pharmacol 1991;31:501-14.

34 Nials AT, Coleman RA, Johnson M, Magunssen H, Rabe $\mathrm{KF}$, Vodey CI. Effects of $\beta$-adrenoceptor agonists in human bronchial smooth muscle. Br $\mathcal{F}$ Pharmacol 1993; 110:1112-6.

35 Anderson GP, Linden A, Rabe KF. Why are long-acting beta-adrenoceptor agonists long-acting? Eur Respir $\mathcal{f}$ 1994;7:569-78.

36 Ball DI, Brittain RT, Coleman RA, Denyer LM, Jack D, Johnson $M$, et al. Salmeterol, a novel, long-acting $\beta_{2^{-}}$ adrenoceptor agonist: characterisation of pharmacological activity in vitro and in vivo. $B r \mathcal{F}$ Pharmacol 1991;104: 665-71

37 Dey RD, Shannon WA, Said SI. Localisation of VIP-immunoreactive nerves in airways and pulmonary vessels of dogs, cats and human subjects. Cell Tissue Res 1981;220 231-8.

38 Robberecht P, Chatelain P, De Neef P, Camus J-C, Waelbroeck M, Christophe J. Presence of vasoactive intestinal peptide receptors coupled to adenylate cyclase in rat lung peptide receptors coupled to adenylate cyclase in rat

39 Palmer JB, Cuss FMC, Barnes PJ. VIP and PHM and their role in non-adrenergic inhibitory responses in isolated human airways. F Appl Physiol 1986;61:C115-9.

40 Hulsmann AR, Jongejan RC, Rolien Ratgeep H, Stignen T, Bonta IL, Kerrebijn KF, et al. Epithelium removal and peptidase inhibition enhance relaxation of human airways
to vasoactive intestinal peptide. Am Rev Respir Dis 1993; 147:1483-6.

41 Kanemura T, Tamaoki J, Chiyotani A, Takeyama K, Saka $\mathrm{N}$, Tagaya $\mathrm{E}$, et al. Role of $\mathrm{Na}^{+} / \mathrm{K}^{+}$ATPase in airway smooth muscle relaxation by vasoactive intestinal peptide and pituitary adenylate cyclase activating peptide. Res Commun Chem Pathol Pharmacol 1993;79:11-22.

42 Gardiner PJ. The effects of some natural prostaglandins on isolated human ciruclar bronchial muscle. Prostaglandins 1975;10:607-16.

43 Sweatman WJF, Collier HOJ. Effects of prostaglandins on human bronchial muscle. Nature 1968;217:69.

44 Armour CL, Johnson PRA, Alfredson ML, Black JL. Characterisation of contractile prostanoid receptors on human airway smooth muscle. Eur F Pharamacol 1989;165:21522.

45 Coleman RA, Kennedy I, Humphrey PPA, Bunce K, Lumley P. Prostanoids and their receptors. In: Emmett JC, ed. Comprehensive medicinal chemistry. Vol 3. Oxford: Pergamon Press, 1990:643-714.

46 Tamaoki J, Chiyotani A, Takayama K, Yamanchi F, Tagaya E, Konno K. Relaxation and inhibition of contractile E, Konno $\mathrm{K}$. Relaxation and inhibition of contractile response to electrical field stimulation by Beraprost so-
dium in canine airway smooth muscle. Prostaglandins dium in canine

47 Araki N, Takagi K. Relaxant effect of pituitary adenylate cyclase-activating polypeptide on guinea-pig trachea smooth muscle. Eur $\mathcal{F}$ Pharmacol 1992;216:113-7.

48 Suzuki K, Takagi K, Satake T, Sugiyama S, Osawa T. The relationship between tissue levels of cyclic GMP and tracheal smooth muscle relaxation in the guinea pig. Clin Exp Pharmacol Phys 1986;13:39-46.

49 Walter U. Physiological role of cGMP and cGMP-dependent protein kinase in the cardiovascular system. Rev Physiol Biochem Pharmacol 1989;113:41-88.

50 Takio K, Wado RD, Smith SB, Krebs EG, Walsh KA, Titani $\mathrm{K}$. Guanosine cyclic $3^{\prime}-5^{\prime}$-phosphate protein kinase, a chimeric protein homologous with two separate protein families. Biochemistry 1984;23:4207-18.

51 Hogaboom GK, Emler CA, Butcher FR, Fedan JS. Concerted phosphorylation of endogenous tracheal smooth muscle membrane proteins by $\mathrm{Ca}^{2+}$-calmodulin-cyclic GMP-, and cyclic AMP-dependent protein kinases. FEBS Lett 1982;139:309-12.

52 Felbel J, Trockur B, Ecker T, Landgraf W, Hofmann F. Regulation of cytosolic calcium by CAMP and CGMP in Regulation of cytosolic calcium by cAMP and cGMP in
freshly isolated smooth muscle cells from bovine trachea. f Biol Chem 1988;263:16764-71.

53 Pfitzer G, Ruegg JC, Flockerzi V, Hofmann F. cGMPdependent protein kinase decreases calcium sensitivity of skinned cardiac fibres. FEBS Lett 1982;149:171-5.

54 McGrogan I, Lu S, Hipworth S, Sormaz L, Eng R, Preocanin
$\mathrm{D}$, et al. Mechanisms of cyclic nucleotide induced relaxation in canine tracheal smooth muscle. Am $\mathcal{f}$ Physio 1995; 12:L407-13.

55 Murphy KS, Severi C, Grider JR, Makhlouf GM. Inhibition of IP3 and IP3-dependent $\mathrm{Ca}^{2+}$ mobilisation by cyclic nucleotides in isolated gastric muscle cells. Am f Physiol 1993;264:G967-74.

56 Katsuki S, Murad F. Regulation of adenosine cyclic $3^{\prime}, 5^{\prime}-$ monophosphate and guanosine cyclic $3^{\prime}, 5^{\prime}$-monophosphate levels and contractility in bovine tracheal smooth muscle. Mol Pharmacol 1976;13:330-41.

57 Gruetter CA, Childers CE, Bosserman MK, Lemke SM, Ball JG, Valentovic MA. Comparison of relaxation induced by glyceryl trinitrate, isosorbide dinitrate, and sodium nitroprusside in bovine airways. Am Rev Respir Dis 1989;140:1192-7.

58 Hamaguchi $M$, Ishibashi $T$, Imai S. Involvement of charybdotoxin sensitive $\mathrm{K}^{+}$channel in the relaxation of bovine tracheal smooth muscle by glyceryl dinitrate and sodium tracheal smooth muscle by glyceryl dinitrate and sodium

59 Qian Y, Haline E, Karlsson JA, Raeburn D, Advenier C. Effects of rolipram and siguazodan on the human isolated bronchus and their interaction with isoprenaline and sodium nitroprusside. Br $\mathcal{F}$ Pharmacol 1993;109:774-8.

60 Jansen A, Drazen J, Osborne JA, Brown R, Loscalzo J, Stamler JS. The relaxant properties in guinea pig airways of S-nitrosothiols. F Pharmacol Exp Ther 1992;261:154-9.

61 Buga GM, Gold ME, Wood KS, Chandhuri G, Ignarro LS Endothelium: derived nitric oxide releases non-vascula smooth muscle. Eur f Pharmacol 1989;161:61-72.

62 Gaston B, Drazen JM, Loscalzo J, Stamler JS. The biology of nitrogen oxides in the airways. Am 7 Respir Crit Care Med 1994;149:538-51.

63 O'Donnell M, Garippa R, Welton AF. Relaxant effect of atriopeptins in isolated guinea-pig airway and vascular smooth muscle. Peptides 1985;6:597-601.

64 Ishii K, Murad F. ANP relaxes bovine tracheal smooth muscle and increases cGMP. Am $\mathcal{F}$ Physiol 1989;256(Cell Physiol 25):C495-500.

65 Fernandes LB, Preuss JM, Goldie RG. Epithelial modulation of the relaxant activity of atriopeptides in rat and guinea pig tracheal smooth muscle. Eur F Pharmacol 1992; 212:187-94.

66 Labat C, Novel Y, Benveniste J, Bukk C. Vasorelaxant effect of atrial peptide II on isolated human pulmonary muscle preparation. Eur $₹$ Pharmacol 1988;150:387-400

67 Candenas ML, Naline E, Puybasset L, Devillier P, Advenier C. Effect of atrial natriuretic peptide and of atriopeptins on the human isolated bronchus. Comparison with the reactivity of the guinea pig isolated trachea. Pulmonol Pharmacol 1991;4:120-5.

68 Hulks G, Crabb K, McGrath JC, Thomson NC. In vitro effects of atrial natriuretic factor and sodium nitroprusside on bronchomotor tone in human bronchial smooth muscle. Am Rev Respir Dis 1991;143:A344.

69 Takagi K, Araki N. Relaxant effects of brain natriuretic peptide on guinea-pig tracheal smooth muscle. Clin Exp Pharmacol Physiol 1993;20:239-43.

70 Takagi K, Araki N, Suzuki K. Relaxant effect of C-type natriuretic peptide on guinea-pig tracheal smooth muscle. Arzneimittelforschung 1992;42:1329-31.

71 Torphy TJ, Undem BJ. Phosphodiesterase inhibitors: new opportunities for the treatment of asthma. Thorax 1991; 46:512-23.

72 Persson CGA, Karlsson JA. In vitro responses to bronchodilator drugs. In: Jenne JW, Murphy S, eds. Drug therapy for asthma. New York: Marcel Dekker, 129-76.

73 Svedmyr N. Treatment with $\beta$-adrenostimulants. Scand $f$ Respir Dis 1977;101:59-68.

74 Beavo JA, Reifsnyder DH. Primary sequence of cyclic nucleotide phosphodiesterase isoenzymes and the design of
selective inhibitors. Trends in Pharmacological Science 1990; 11:150-5.

75 Loughney K, Ferguson KM. The human cyclic nucleotide phosphodiesterase. In: Costello JF, Piper PJ, eds. Methylxanthines and phosphodiesterase inhibitors in the treatment xanthines and phosphodiesterase inhibitors in the treatment

76 Tomkinson A, Karlsson JA. Raeburn D. Comparison of the effects of selective inhibitors of phosphodiesterase types III or IV in airway smooth muscle with differing $\beta$ adrenoceptor subtype. Br f Pharmacol 1993;108:57-61.

77 Giembycz MA, Belvisi MG, Miura M, Perkins RS, Kelly J, Tadjkarimi S, et al. Soluble cyclic nucleotide phosphodiesterase isoenzymes from human tracheal smooth muscle. Br f Pharmacol 1992;107:52P

78 Belvisi MG, Miura M, Peters MJ, Ward JK, Tadjkarimi S, Yacoub MH, et al. Effect of isoenzyme-selective cyclic nucleotide phosphodiesterase inhibitors on human tracheal smooth muscle tone. Brf Pharmacol 1992;107:53.

79 Rabe KF, Tenor H, Dent G, Schudt C, Liebig S, Magnussen H. Phosphodiesterase isoenzymes modulating inherent tone in human airways: identification and chartone in human airways: identification and

80 Foster RW, Okpalugo MI, Small RC. Antagonism of $\mathrm{Ca}^{2+}$ and other actions of verapamil in guinea pig isolated

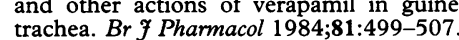

81 Black J, Armour C, Johnson P, Vincenc K. The calcium dependence of histamine, carbachol and potassium chloride-induced contraction in human airways in vitro. Eur f Pharmacol 1986;125:159-68.

82 Drazen JM, Fanta CH, Lacontre PG. Effect of nifedipine on constriction of human tracheal strips in vitro. $\mathrm{Br} \mathcal{F}$ Pharmacol 1983;78:687-91.

83 Weichman BM, Muccitelli RM, Tucker SS, Wasserman MA. Effect of calcium antagonists on leukotriene $D_{4^{-}}$ 
induced contractions of the guinea-pig trachea and lung parenchyma. 7 Pharmacol Exp Ther 1983;225:310-5.

84 Advenier C, Cerrina J, Duroux P, Floch A, Renier A. Effect of five different calcium antagonists on guinea pig isolated trachea. Br $\mathcal{F}$ Pharmacol 1984;82:727-33.

85 Burka JF. Effects of calcium channel blockers and a calmodulin antagonist on contractions of guinea pig airways Eur $\mathcal{F}$ Pharmacol 1984;99:257-68.

86 Henderson AF, Heaton RW, Dunlop LS, Costello JF. Effects of nifedipine on antigen-induced bronchoconstriction. Am Rev Respir Dis 1983;127:549-53.

87 Murray MA, Kotlikoff MI. Receptor-activated calcium influx in human airway smooth muscle cells. F Physiol 1991; 435:123-44.

88 Kirkpatrick CT. Excitation and contraction in bovine tracheal smooth muscle. F Physiol 1975;244:263-81.

89 Stephens NL, Kroeger EA, Kromer U. Induction of a myogenic response in tonic airway smooth muscle by tetraethylammonium. Am f Physiol 1975;228:628-32.

90 McCann JD, Welsh MJ. Calcium-activated potassium channels in canine airway smooth muscle. $\mathcal{F}$ Physiol 1986;372 $113-27$.

91 Kotlikoff MI. Potassium currents in canine airway smooth muscle cells. Am f Physiol 1990;259 (Lung Cell Mol Physio 3):L394-5

92 Marthan R, Martin C, Thierry A, Mironnuea J. Calcium channels in isolated smooth muscle cells from human bronchus. I Appl Physiol 1989;66:1706-14.

93 Hisada T, Yoshihisa K, Tsuneaki S. Properties of membrane current from guinea-pig trachea. Pflugers Arch 1990;416: 151-61.

94 Murray MA, Berry JL, Cook SJ, Foster RW, Green KA, Small RC. Guinea-pig isolated trachealis: the effects of charybdotoxin on mechanical activity, membrane potential changes and the activity of plasmalemmal $\mathrm{K}^{+}$ channel. F Biol Chem 1991;261:14607-13.

95 Miura M, Belvisi MG, Stretton CD, Yacoub MH, Barnes PJ. Role of potassium channels in bronchodilator responses in human airways. Am Rev Respir Dis 1992;146:132-6.

96 Huang JC, Garcia ML, Reuben JP, Kacsorowski GJ. Inhibition of beta agonist relaxation of airway smooth muscle by $\mathrm{Ca}^{2+}$ activated $\mathrm{K}^{+}$channel blockers. Eur $\mathfrak{f}$ Pharmacol 1993;235:37-43.

97 Taylor SG, Bumstead J, Morris JEJ, Shaw DJ, Taylor JF Cromakalim inhibits cholinergic-mediated responses in human isolated bronchioles but not in guinea-pig airways. human isolated bronchioles but

98 Hall AK, Maclagan J. Effect of cromakalim on cholinergic neurotransmission in the guinea-pig trachea. $\mathrm{Br} \mathcal{F}$ Phar macol 1988;96:792P.

99 Black JL, Armour CL, Johnson PRA, Alouan LA, Barnes PJ. The action of a potassium channel activator BRI 38227 (lemakalim) on human airway smooth muscle. $A m$ Rev Respir Dis 1990;142:1384-9.

100 Buckle DR, Arch JR, Bownig NE, Foster KA, Taylor JF,
Taylor SG, et al. Relaxant effects of the potassium channel activators BRL 38227 and pinacidol on guinea pig and human airway smooth muscle, and blockade of their effects by glibenclamide and BRI 31660. Pulmonol Pharmacol 1993;6:77-86.

101 Cortijo J, Sarria B, Pedros C, Perpina M, Paris F, Morcillo E. The relaxant effects of cromakalim (BRL 34915) on human isolated smooth muscle. Naunyn Schmiedebergs Arch Pharmacol 1992;346:462-8.

102 Black JL, Barnes PJ. Potassium channels and airway function: new therapeutic prospects. Thorax 1990 45:213-8.

103 Krampetz IK, Bose R. Relaxant effect of amiloride on canine tracheal smooth muscle. F Pharmacol Exp Ther 1988;246:641-8.

104 Knox AJ, Ajao P, Britton JR, Tattersfield AE. The effect of sodium transport inhibitors on airway smooth muscle of sodium transport inhibitors on airway smoo

105 Souhrada M, Souhrada MH, Souhrada JF. The inhibition of sodium influx attenuates airway response to a specific antigen challenge. $B r \mathcal{F}$ Pharmacol 1988;93:884-92.

106 Yu J, Guia A, Minks S, Kepron W, Cragoe EJ Jr, Sharm $S$, et al. Role of sodium in antigen-induced contraction of tracheal smooth of dogs. Respir Physiol 1993;91: 11-124

107 Knox AJ, Ajao P. The effect of inhibitors of $\mathrm{Na}^{+} / \mathrm{H}^{+}$ exchange on airway smooth muscle contractility. Pulmonol Pharmacol 1994;7:99-102.

108 Knox AJ, Britton JR, Tattersfield AE. Effect of sodiumransport inhibitors on bronchial reactivity in vivo. Clin transport inhibitors

109 Nagai H, Yamada H, Goto S, Inagaki N, Koda A. Reduction of antigen-induced contraction of sensitised guinea-pig tracheal smooth muscle in vitro by calmodulin inhibitors. Int Archs Allergy Appl Immunol 1985;76: 251-5.

110 Souhrada M, Souhrada JF. The role of protein kinase C in sensitisation and antigen response of airway smooth muscle. Am Rev Respir Dis 1989;140:1567-72.

111 Venugopalan CS, O'Rourke YM, Tucker TA. Bronchorelaxing activity of lithium in vitro. 7 Pharmacol Sci 1985 74:1120-2.

112 Knox AJ, Higgins BG, Hall IP, Tattersfield AE. The effect of lithium on bronchial reactivity in asthma. Clin $S c i$ of lithium on b

113 Hashimoto Y. Comparison of the relaxant effects of diazepam, flurazepam and midazolam on airway smooth azepam, flurazepam and midazolam
muscle. Br 7 Anaesth 1992;69:65-9.

114 Yamakage effects of four inhaled anesthetics on canine tracheal smooth muscle contraction and intracellular $\mathrm{Ca}^{2+}$ concentration. Anesth Analg 1993;77:67-72.

115 Wilson LE, Hatch DJ, Rehder K. Mechanisms of the relaxant action of ketamine on isolated porcine trachealis muscle. Br F Anaesth 1993;71:544-50. 